
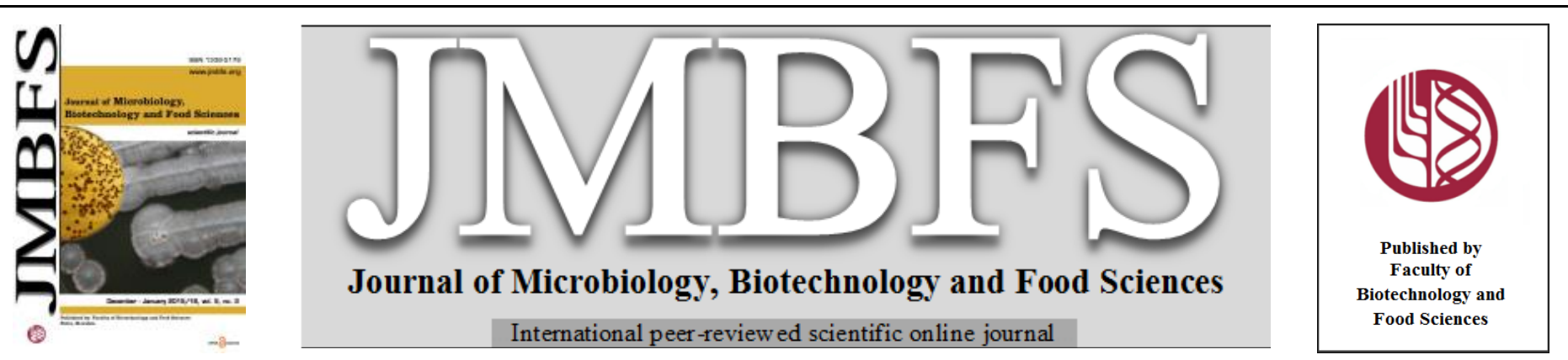

\title{
EXAMINATION OF ENERGY RECOVERY OF BREWERS' SPENT GRAIN II. - BIOLOGICAL PROCESS
}

\author{
Gábor Géczi ${ }^{* 2}$, Catarina Azevedo Borges ${ }^{l}$, Csaba Ágoston ${ }^{7}$, Krisztina Pusztai $^{7}$, Ákos Ulmer $^{7}$, Sándor Beszédes ${ }^{8}$
}

$\operatorname{Address}(e s)$ :

${ }^{2}$ Szent István University, Faculty of Mechanical Engineering, Institute of Environmental Systems, Department of Environmental and Building Engineering, Gödöllő, Hungary

${ }^{1}$ Federal University of Minas Gerais, Belo Horizonte, Brazil (Scholar of the Science Without Borders at Szent István University in Gödöllő, Hungary)

${ }^{7}$ Environmental Testing Agency Ltd, Budapest, Hungary

${ }^{8}$ Department of Process Engineering, Faculty of Engineering, University of Szeged, Hungary

*Corresponding author: geczi.gabor@gek.szie.hu

doi: 10.15414/jmbfs.2015/16.5.3.268-270

\section{ARTICLE INFO}

Received 26. 6. 2015

Revised 2. 10. 2015

Accepted 14. 10. 2015

Published 1. 12. 2015

Regular article

open 2 access

\section{ABSTRACT}

Production rate of technologies applied in the food industry can only be economical if energy consumption is specifically reduced simultaneously with increasing the capacities and/or utilization of alternative energy sources gains higher ratio during production. A high proportion of waste forms is produced in food processing technologies. Fiscal and environmental cost of waste handling i.e. transportation, recovery and disposal is often significant.

Brewing industry's most important by-product is the brewers' spent grains (BSG) formed during mashing. Utilization of this product is theoretically solved, it is most frequently sold as animal fodder, however utilization in the energy sector can and should be considered and has promising possibilities. Seeking economic and environmental benefits, this paper analyses the possibilities of energy recovery from brewers' spent grains through aerobic digestion and anaerobic fermentation.

Keywords: Brewers' spent grains (BSG), energy recovery, aerobic digestion, fermentation

\section{INTRODUCTION}

The largest scale byproduct of beer brewing is brewers' spent grains which is a residue of mashing (Bourges et al., 2015; Mussatto et al., 2006). Leaving the mashing tank, it is still hot and has high humidity content (w>70\%). Storage is an issue in this state due to fermentation processes and forming odors. Brewers spent grains are most commonly utilized as animal fodder as well as for manufacturing of complementary food for human consumption. Apart from this, it might be sold as organic manure after composting; based on the above told, the breweries' waste-recycling can be considered as solved (Aliyu and Bala, 2011; White et al., 2008). Nevertheless, breweries still need alternative energy resources to cover their energy demand, even if only partially possible. Numerous procedures of brewing - ie. grinding, circulating the liquid, cooling, mashing, hop boiling - require heat or electric energy (Bamforth, 1998; Briggs, 1998; Géczi et al., 2014; 2011; Narzis, 1981).

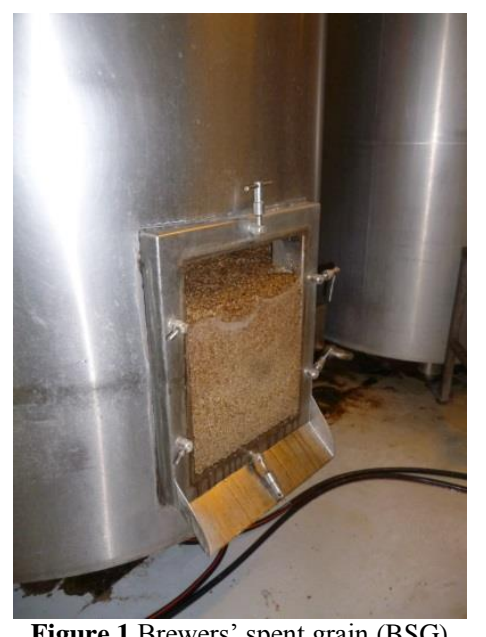

Figure 1 Brewers' spent grain (BSG) Source: HBH Brewery, Táborfalva
A good example for energetic utilisation of waste/by-product by biological processes is the case of Magyar Cukor Rt. - the sugar production facility in Kaposvár. For covering of heat- and electric energy demand of sugar beet processing, the facility had been using exclusively natural gas before 2007, as primary energy resource. According to environmental and energetic aspects, two anaerobic fermenters were installed in 2007, that are suitable to ensure the local energy demand of the factory, substituting the natural gas for the produced biogas, using the sugar beet slices left over from the beet-processing as raw material for anaerobic digestion technology (http2).

Several dairy farms in Hungary reduce their electric energy-demand by producing biogas, subsequently generating electricity by means of using gasengines (Csomád, Pusztahencse, Pálhalma). Treatment of the forming slurry- or solid (strawy) manure is solved by fermentation and therefore the facility's or the connecting food-plants' heating or warm water supply can be sorted out.

The most plausible method for energetical utilisation of brewers' spent grains is combustion. But even small-scale facilities prefer to use gas-operated instruments both for water-heating and hop-boiling, furthermore BSG-heating value examination also show contradictory results. It is a fact that humidity content of the formed waste is very high, therefore it is not appropriate for combustion in this form. Pre-treatment by means of drying would require further energy-input, the humidity-reduction via natural process - exposed to direct sunlight - needs huge amount of space due to large volume and is severely impacted by environmental circumstances. The recently re-discovered technology of pyrolysis can be considered an expensive method but based on our research results, biocoal originating from thermal conversion offers a promising possibility (Lányi, et al. 2014).

By means of anaerobic fermentation, mixed with other organic substances, brewer's spent grains might be converted into biogas, which - just like the examples already presented - would cover the energy demands at the very place where they arise, in an environmentally conscious way (Xiros et al. 2008; Xiros and Christakopoulos, 2009).

After removing brewer's spent grains from the mashing tub, the biological processes initialise right away. Examining the biological processes, such as anaerobic fermentation and composting, is justified not only due to the search for alternative energy-resources but by the issues related to forming odors. Our experimental results related to modeling the biological processes are presented below. 


\section{MATERIAL AND METHODS}

Examination of biological processes under laboratory circumstances began with a simple storage experiment. $150-150 \mathrm{~g}$ brewer's spent grains were placed in $1000 \mathrm{~cm}^{3}$ vials under aerobic and anaerobic conditions. The gas production ability of the samples under anaerobic conditions were checked by using an inflating sack (Figure 2).

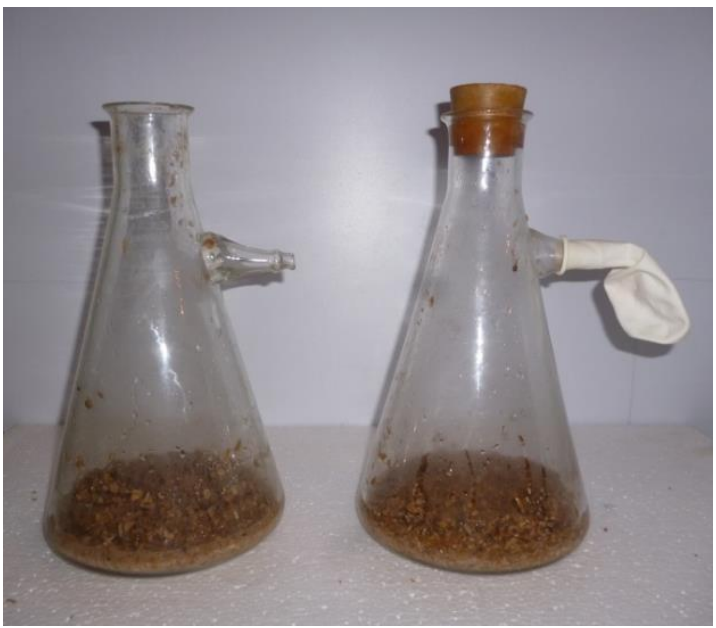

Figure 2 Examining BSG samples under aerobic and anaerobic conditions.

Under aerobic conditions (Figure 2, left), the decomposition process involves significant odor formation. This is one of the heaviest problem for the breweries, the BSG removal must be taken care of continuously, as soon as possible. The polluting substance or mixture of these substances with smell-effect is called the odor. The odor concentration can be expressed in odor units per cubic meter of air $\left(\mathrm{OU} / \mathrm{m}^{3}\right)$, using the olfactometry measuring method (MSZ EN 13725:2003). The perception threshold of an odorous gas is defined as the gas concentration in $1 \mathrm{~m}^{3}$ standard gas containing odorous substance at which $50 \%$ of human observers perceive. Odor concentration is the count of odor units in 1 standard $\mathrm{m}^{3}$ odorous substance containing gas, unit of measurement is odor unit $/ \mathrm{m}^{3} \mathrm{OU} / \mathrm{m}^{3}$ (Béres, 2014; Béres et al., 2014). The odor concentration formed during storage of brewer's spent grains was checked at the site of KVI PLUSZ Ltd. every 2-3 days by means of olfactometry method. This is unrelated to an odor quality determination.

For breweries, an alternative energy resource could be the biogas which is produced from organic waste (for example BSG) under anaerobic conditions. The (bio)gas production was not started without addition of other organic materials during the examined 1 month period (Figure 2, right) in case of degradation process. We implemented examinations on biogas production by means of anaerobic biodegradation of the aqueous suspension of brewers' spent grains mixed with seed sludge - originating from food industry wastewater. In the laboratory of Faculty of Engineering at the University of Szeged, we monitored the gas generation in a continuously stirred and temperature controlled laboratory biogas measurement system using $250 \mathrm{~cm}^{3}$ capacity reactors. The reactors equipped with Oxitop-C pressure sensors (WTW, Germany) were placed into incubators to ensure the constant temperature of $37 \pm 0.2^{\circ} \mathrm{C}$ during the $\mathrm{AD}$ tests (Figure 3).The volume of formed biogas is proportional to the pressure increase of sealed reactors, composition of biogas may be controlled by means of chromatograph

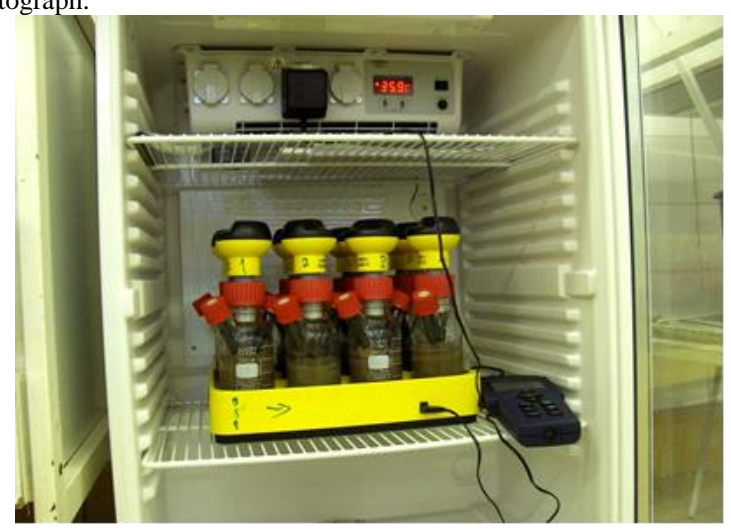

Figure 3 Oxitop-C anaerobic digestion apparatus

The volume of biogas, which may be yielded from anaerobic methods, may further be enhanced by using heat- and chemical pre-treatment methods. For microwave processing, a suspension was made from BSG $(25 \mathrm{~g}$ BSG+75g distilled water) and the $\mathrm{pH}$ was adjusted 7.2 and 12 , by $\mathrm{NaOH}$ and hydrochloric acid dosing. Heat treatment was executed in a microwave instrument and heating plate. The microwave pre-treatments were carried out in Labotron 500 type professional equipment using $250 \mathrm{~W}$ and $500 \mathrm{~W}$ magnetron power respectively. Depending on the applied microwave power the heating time was varied in the range of $1-30$ minutes, the temperature of suspension reached $70-95^{\circ} \mathrm{C}$. For conventional heating $(\mathrm{CH})$ a hot-plate stirrer equipped with temperature controller was applied. The target temperature was $85-90^{\circ} \mathrm{C}$. The quantity and composition of BSG samples are the same as used for microwave pre-treatments.

\section{RESULTS AND DISCUSSION}

No decomposition process involving gas-generation - without adding further substances - was triggered under anaerobic circumstances during our experiments (Figure 2. right). In spite of this, the aerobic process which took place in the open vial resulted in reasonable odor effect. The BSG sample was stored in open plastic box during the investigation. Figure 4 show the odor concentration of BSG as a function of time (days) by olfactometry method. In the first two days the odor was sweet, malt reminder, but later the odor was unpleasant, smelly and fermented. The odor unit $\left(\mathrm{OU} / \mathrm{m}^{3}\right)$ after the $5^{\text {th }}$ day storage was the highest, after which it started to decrease. Based on the experiment this storage methodology does not allow the BSG to dry. This drying can be ensured by spreading out the BSG, after which the smelly odor ceases and the malt odor returns (data not shown).

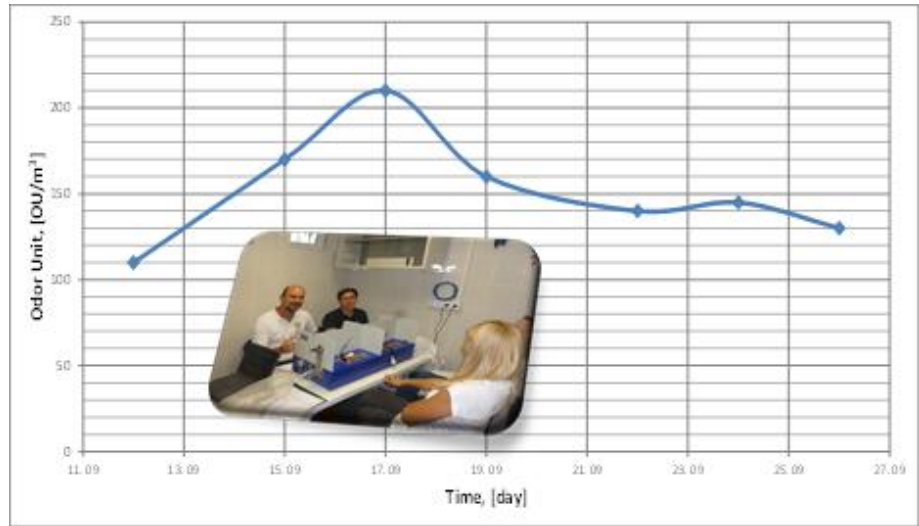

Figure 4 Odor concentration of BSG as a function of time.

For waste disposal the brewers' spent grains by means of aerobic biological methods, composting experiments were also implemented. Producing natura manure originating from composting is a longer process, utilising the substance gained from aerobic decomposition holds an opportunity rather for the agricultural sectors not for energy recovery. Experiments in progress (data not shown).

Anaerobic neutralization under laboratory circumstances by adding bioenzymes, bacteria, microorganisms and mixtures of specific micronutrients (MicrocatDEN, DNT, UASB, Bioscience, Inc., Allentown, Pennsylvania USA) was also carried out. Gas forming already started but the used chemicals did not resulted in methane gas production. The gas was analyzed by gas chromatography, and did not show the presence of methane.

The biogas volume was calculated from the pressure increase in the sealed reactors. The volumetric biogas production rate was given in $\mathrm{mL} \cdot \mathrm{day}^{-1}$ units normalized to $20^{\circ} \mathrm{C}$ in Figure 5. Inoculum for $\mathrm{AD}$ experiments is originated from a digester of a local wastewater treatment plant. Seed sludge was dosed in a concentration of $20 \mathrm{w} / \mathrm{w} \%$, referred to the total quantity of sample. Control sample (referred as Cont.) contained the BSG and the seed sludge, but it was not treated by microwave or conventional heating. 


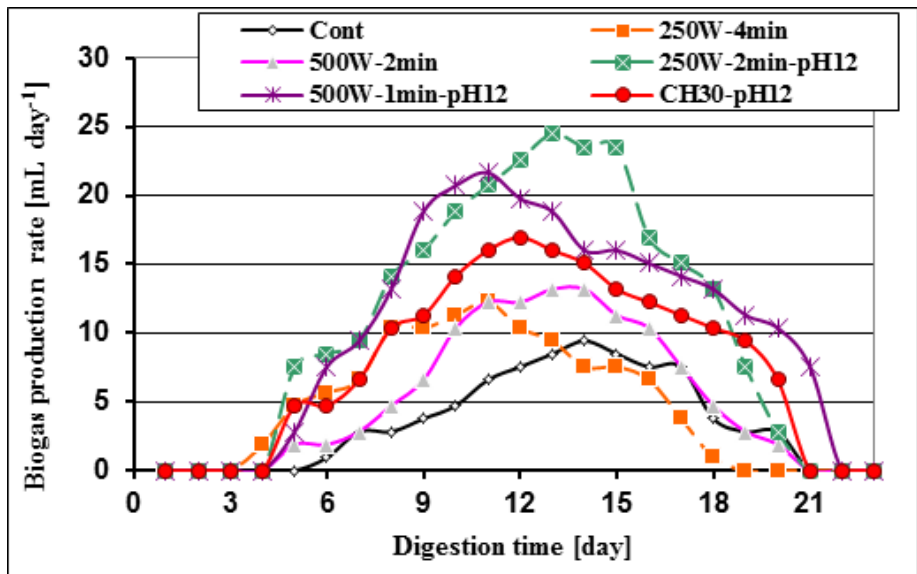

Figure 5 Biogas production rate as a function of digestion time

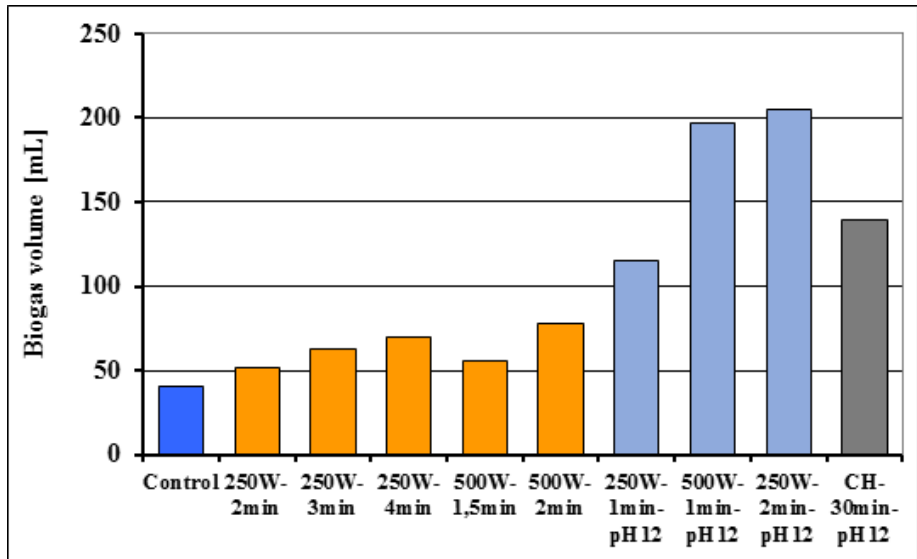

Figure 6 Cumulative biogas volume of control and pre-treated BSG produced in batch mesophilic $\mathrm{AD}$ tests (digestion time $=23$ days, $\mathrm{t}=37 \pm 0.2^{\circ} \mathrm{C}$ )

The cumulative biogas volume - gained in 23 days' time - can be seen on Figure 6 as a function of the pre-treatment methods. As it is shown, the biogas production rate compared with the control sample - the sample without heat- and chemical treatment, but mixed with seed sludge - increased in all cases. Intensity of microwave treatment and duration of that also increased gas forming in a linearly proportional pattern. Setting of $\mathrm{pH}$ to 12 during the microwave pretreatment process led to an significant increment of biogas production rate and biogas yield as well.

Our results show, that BSG co-fermented by wastewater sludge from food industry is suitable to biogas generation. The degree and quality of biogas can be further improved by heat- and chemical treatment.

\section{CONCLUSION}

$85 \%$ of the total by-product of the brewing industry is brewers' spent grains (BSG). Aiming economic and environmental benefits, this research analyses the possibilities of energy recovery of BSG, through aerobic digestion and anaerobic fermentation properties of this waste. Our experimental results verified, that biological degradation process during the storage of BSG led to a significant odor emission. This forces the small and medium sized factories to find economical, and environmental friendly processes for organic waste disposal. Based on the results of our earlier research, the chemical and thermo-chemical treatment processes can be considered as efficient method for waste treatment, but the high investment and operational cost of pyrolysis and burning make the wide spread using of these process limited in industrial scale technologies. Application of biological process in the handling of BSG propose other problems, anaerobic digestion of BSG raw material produce slight amount of methane, and in many cases the methanogenesis phase of anaerobic decomposition process is inhibited But because of the high organic matter content, BSG can be suitable to biogas generation co-fermented by sludge or other organic waste and by-products of food industry and animal husbandry, respectively. In that way, the produced biogas from waste and by-products could cover the local energy demand of the main technological processes, furthermore could provide economical feasibility for waste handling and disposal. Our present experimental results are also verified, that biogas yield and biogas production rate can be enhanced by the appropriate mixing ratio of different raw materials, and furthermore application of suitable pre-treatment method, such as microwave irradiation, or its combination with alkaline treatment methods.
Acknowledgements: We would like to express our appreciation to $\mathrm{HBH}$ brewery in Táborfalva and Legenda brewery in Budapest, since they continuously provided the BSG samples which were crucial for the experiments.

\section{REFERENCES}

ALIYU, S., BALA, M. 2011. Brewer's spent grain: A review of its potentials and applications. African Journal of Biotechnology, 10(3), 324-331.

BAMFORTH, C.W. 2006. Scientific Principles of Malting and Brewing American Society of Brewing Chemists, 246 p. ISBN-13 978-1881696087. BÉRES, A. 2014. Az állattartás környezeti szaghatása, a szagvédelmi szabályozás lehetséges módszerei Gradus 1:(2) pp. 147-152. BÉRES, A., GULYÁS M., ALEKSZA L. 2014. Biohulladék-kezelő létesítmények szagkibocsátása, Mezögazdasági Technika 55:(9) pp. 2-5. BRIGGS, D.E. 1998. Malts and Malting. Blackie Academic \& Professional, London, 796 p. ISBN-13: 978-0412298004

BOURGES, A.C., GÉCZI, G., KOVÁCS, K., HORVÁTH, M., BÁCSKAI, I., KORZENSZKY, P. 2015. Examination of Energy Recovery of Brewers' Spent Grain I. - Chemical Process, Journal of Microbiology, Biotechnology and Food Sciences, vol. 5(2) 116-119. doi: 10.15414/jmbfs.2015.5.2.116-119 GÉCZI, G., HORVÁTH, M., DRÁB, Š., TÓTH, Ž., BENSE, L. 2014. Effect of Malt Milling for Wort Extract Content, Potravinarstvo, 8(1), 33-37. http://dx.doi.org/10.5219/326

LÁNYI, K., MOLNÁR, E.,VANÓ I., KORZENSZKY P. 2014. Looking Behind The Process of Pyrolysis in Waste Management: Questions on The Composition and Quality of End-Product and Their Answers by Meas of Analytical Chemistry Hungarian Agricultural $\quad$ Engineering 26.28 http://dx.doi.org/10.17676/HAE.2014.26.25

MUSSATTO, S.I., DRAGONE, G., ROBERTO, I.C. 2006. Brewers' spent grain: generation, characteristics and potential applications Journal of Cereal Science 43, 1-14. http://dx.doi.org/10.1016/j.jcs.2005.06.001

NARZISS, L. 1981. A sörgyártás. (The Beer Production, in hungarian) Mezögazda kiadó, Budapest, 346 p.

WHITE, J.S., YOHANNAN, B.K., WALKER, G.M. 2008. Bioconversion of brewer's spent grains to bioethanol FEMS Yeast Res 8(7) 1175-1184 http://dx.doi.org/10.1111/j.1567-1364.2008.00390.x

XIROS, C., TOPAKAS, E., KATAPODIS, P., CHRISTAKOPOULOS, P. 2008 Hydrolysis and fermentation of brewer's spent grain by Neurospora crassa

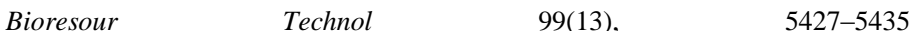
http://dx.doi.org/10.1016/j.biortech.2007.11.010

XIROS, C., CHRISTAKOPOULOS, P. 2009. Enhanced ethanol production from brewer's spent grain by a Fusarium oxysporum consolidated system, Biotechnology for Biofuels 2(4), 12 p. http://dx.doi.org/10.1186/1754-6834-2-4 http2:

http://www.cerealsdb.uk.net/cerealgenomics/WheatBP/Documents/DOC Baking. php 